Ambiente \& Água - An Interdisciplinary Journal of Applied Science
ISSN 1980-993X - doi:10.4136/1980-993X
www.ambi-agua.net
E-mail: ambi.agua@gmail.com

\title{
Losses of soil, water, organic carbon and nutrients caused by water erosion in different crops and natural savannah in the northern Amazon
}

\author{
ARTICLES doi:10.4136/ambi-agua.2126 \\ Received: 24 Apr. 2017; Accepted: 01 Nov. 2018 \\ Fernando Gomes de Souza ${ }^{1 *(D)}$; Valdinar Ferreira Melo ${ }^{2}$; \\ Wellington Farias Araújo ${ }^{2}$; Thiago Henrique de Castro Araújo ${ }^{3}$ \\ ${ }^{1}$ Instituto Federal de Educação, Ciência e Tecnologia de Rondônia (IFRO), Colorado do Oeste, RO, Brasil \\ E-mail: fernando.souza@ifro.edu.br \\ ${ }^{2}$ Universidade Federal de Roraima (UFRR), Boa Vista, RR, Brasil \\ Departamento de Solos e Engenharia Agrícola (DSEA). E-mail: valdinar@yahoo.com.br, \\ wellington.araujo@ufrr.br \\ ${ }^{3}$ Universidade Federal de Roraima (UFRR), Boa Vista, RR, Brasil \\ Centro de Ciências Agrárias. E-mail: thiagohenriaraujo@gmail.com \\ "Corresponding author
}

\begin{abstract}
Currently in Brazil, the main form of erosion is caused by the impact of raindrops on the soil surface, triggering the process of water erosion and causing serious damage to agricultural areas. This study evaluated losses of soil, water, organic carbon and nutrients in different cultures, bare soil and savanna under natural rain. The experimental design was completely randomized with five treatments (bare soil - BS, cowpea bean - $\mathrm{CB}$, Brachiaria brizantha - BB, corn - $\mathrm{CO}$ and natural savanna - SN) with three replications; The treatment of bare soil (BS), followed by the treatment cultivated with cowpea bean (CB) showed higher losses of soil, water, organic carbon and nutrients; The highest losses of soil, water, organic carbon and nutrients in the treatment of bare soil (BS) occurred during the period of greatest erosivity; but for treatments $\mathrm{CB}, \mathrm{BB}$ and $\mathrm{CO}$, the highest losses occurred during the establishment of the crop, in view of the lower soil cover. Soils cultivated with Brachiaria brizantha - BB, corn - CO and in the Natural Savana - SN area were more efficient in reducing soil and water losses during all months evaluated. Plant cover produced by the $(\mathrm{SN})$ treatment and by the $(\mathrm{BB})$ and $(\mathrm{CO})$ treatments acted to reduce the harmful effects of erosion, minimizing losses of nutrients and organic carbon. The soil should be well protected during periods when rainfall presents the highest values of erosivity index.
\end{abstract}

Keywords: losses due to erosion, Roraima, soil degradation, soil management.

\section{Perdas de solo, água, carbono orgânico e nutrientes por erosão hídrica em diferentes cultivos e savana natural no norte da Amazônia}

\section{RESUMO}

Atualmente no Brasil a principal forma de erosão é causada pelo impacto das gotas de chuva na superfície do solo, desencadeando o processo de erosão hídrica e causando sérios danos às áreas agrícolas. Este trabalho foi realizado com o objetivo de avaliar perdas de solo, 
água, nutrientes e carbono orgânico em diferentes culturas, solo descoberto e savana, sob chuva natural. $\mathrm{O}$ delineamento experimental foi inteiramente casualizado com cinco tratamentos (solo descoberto - SD, feijão-caupi - FC, Braquiária brizantha - BB, milho - MI e savana natural $\mathrm{SN}$ ) com três repetições; O tratamento do solo descoberto (SD), seguido do tratamento com feijão-caupi (FC) apresentou maiores perdas de solo, água, nutrientes e carbono orgânico; As maiores perdas de solo, água, nutrientes e carbono orgânico no tratamento do solo descoberto (SD) ocorreram durante o período de maior erosividade, mas para os tratamentos FC, BB e MI ocorreram durante o estabelecimento da cultura, tendo em vista a menor cobertura do solo; Solos cultivados com Brachiaria brizantha - BB, Milho - MI e a área com Savana Natural $\mathrm{SN}$, foram mais eficientes na redução das perdas de solo e água, durante todos os meses avaliados. A Cobertura vegetal proporcionada pelo tratamento $(\mathrm{SN})$ e pelos tratamentos $(\mathrm{BB})$ e (MI) atuaram na redução dos efeitos danosos da erosão, minimizando as perdas de nutrientes e carbono orgânico; O solo deve estar bem protegido durante os períodos em que a chuva apresente os maiores valores do índice de erosividade.

Palavras-chave: degradação do solo, manejo do solo, perdas por erosão, Roraima.

\section{INTRODUCTION}

Water erosion is a physical phenomenon that includes the phases of soil disintegration, transport and deposition, promoted by the action of natural agents such as impact of rainfall and surface runoff (Dechen et al., 2015). It is the main degradation process of agricultural soils by anthropic interference. Water erosion is influenced by the characteristics and distribution of rainfall, soil type, topography, soil cover and management, and by conservationist practices supporting agricultural production (Bertol et al., 2007; Panagos et al., 2015).

Soil erosion is a complex phenomenon, involving the infiltration of water into the soil, the storage of part of the precipitated water and runoff. According to Silva et al. (2005b) and Telles et al. (2013), erosion has contributed to the impoverishment and reduction of the sustainability of agroecosystems by causing the loss of soil, water, nutrients and organic carbon. Besides causing the degradation of agricultural areas, water erosion results in economic, social and environmental damages that can be minimized with the adoption of soil conservation practices important in the control of erosion (Rabelo and Griebeler, 2012).

The best way to avoid damage caused by erosion is by the maintenance or recovery of the physical, chemical and biological conditions of the soil, and by establishing criteria for land use and management, in order not to compromise the land's productive capacity, aiming to increase the availability of water, nutrients and the soil's biological activity, creating adequate growing conditions for plants (Cunha et al., 2017). Soil cover provided by natural vegetation, crops or by the remains of cultures is fundamental to reducing soil, water and nutrient losses due to water erosion (Pires et al., 2006; Panachuki et al., 2011; Volk and Cogo; 2014). Soil cover also acts to reduce the impact force of rainfall, soil disruption, surface sealing and flood velocity, so any change in vegetation cover will directly affect the runoff rate (Zhou et al., 2002; Silva et al., 2005a; Leite et al., 2009; Pugliesi et al., 2011; Cardoso et al., 2012).

In Roraima state, the soil's diversity is a reflection of climatic factors and biotic and landscape characteristics, marked by a reduction of precipitation that occurs in the central area of the State (Melo et al., 2010). Some soils here show cohesion characteristics with severe laminar erosion (Benedetti et al., 2011), features found mainly in the savan nah area, which are areas formed by extensive planed surfaces covered by shrub, grassy-woody and herbaceous vegetation (Feitosa et al., 2016).

Assessing water erosion in the cultivation of Acacia mangium in the savanna area of the State of Roraima, Barros et al. (2009) observed that during the period evaluated, denser acacia 
vegetal cover was the main factor in reducing water erosion. Barbosa and Fearnside (2000), analyzing soil erosion by rainwater in two land uses (primary forest and forest-derived pasture) between August and February 1992 in the region of Apiaú, Roraima, observed that the rate of erosion in pastures $\left(1,128 \mathrm{~kg} \mathrm{ha}^{-1}\right.$ year $\left.^{-1}\right)$, was 7.5 times higher than in the adjacent forest $\left(150 \mathrm{~kg} \mathrm{ha}^{-1}\right.$ year $\left.^{-1}\right)$. This causes the successive degradation of soil fertility and suggests that pastures derived from forests in the Amazon are unsustainable land-use systems for the region. This work evaluated soil, water, nutrient and organic carbon losses in Brachiaria brizantha, cowpea bean (Vigna unguiculata), corn (Zea mays), bare soil and natural savanna.

\section{MATERIALS AND METHODS}

\subsection{Localization and Characterization of the study area}

The experiment was conducted at the experimental unit of the Center of Agricultural Sciences (CCA), the Cauamé Campus of the Federal University of Roraima (UFRR), Boa Vista - RR, geographical reference coordinates $2^{\circ} 52^{\prime} 16^{\prime \prime} \mathrm{N}$ and $60^{\circ} 42^{\prime} 47^{\prime \prime} \mathrm{W}$.

The soil of the experimental unit was classified as a Dystrophic Yellow Latosol (Xantic Hapludox, Soil Taxanomy) (Embrapa, 2013), soil with low natural fertility, originated from pre-weathered clayey-sandy sediments of the Boa Vista formation (Benedetti et al., 2011), positioned in flat relief at a mean altitude of $80 \mathrm{~m}$ (Table 1).

Table 1. Soil chemical analysis of the experimental area at Campus do Cauamé at UFRR.

\begin{tabular}{|c|c|c|c|c|c|c|c|c|c|c|c|c|c|}
\hline \multirow{3}{*}{ Depth } & \multirow{3}{*}{$\mathrm{pH}$} & \multicolumn{8}{|c|}{ Sortive Complex } & \multirow{2}{*}{ V } & \multirow{2}{*}{$\mathrm{m}$} & \multirow{2}{*}{$\mathrm{P}$} & \multirow{2}{*}{$\mathrm{C}$} \\
\hline & & $\mathrm{Ca}^{2+}$ & $\mathrm{Mg}^{2+}$ & $\mathrm{K}^{+}$ & $\mathrm{Al}^{3+}$ & $\mathrm{H}^{+}+\mathrm{Al}^{3+}$ & S & CECe & $\mathrm{CECt}$ & & & & \\
\hline & & \multicolumn{8}{|c|}{$\mathrm{cmol}_{\mathrm{c}} \mathrm{dm}^{-3}$} & \multicolumn{2}{|c|}{$\%$} & $\mathrm{mg} \mathrm{dm^{-3 }}$ & $\mathrm{g} \mathrm{dm}^{-3}$ \\
\hline $0-15$ & 5.18 & 081 & 0.25 & 0.02 & 1.60 & 2.26 & 1.08 & 2.68 & 3.34 & 32.34 & 59.70 & 5.05 & 10.01 \\
\hline $15-30$ & 4.21 & 3.38 & 0.10 & 0.01 & 2.40 & 3.65 & 3.49 & 5.89 & 7.14 & 48.88 & 40.75 & 3.89 & 6.19 \\
\hline
\end{tabular}

pH: in water; S: sum of bases; CECe: Effective CEC; CECt: total CEC; V: base saturation; m: Al saturation; P: available phosphorus, and C: organic carbon.

The dystrophic yellow latosols that occupy $22 \%$ of the Roraima state are soils of low natural fertility, with physical problems when dry (they are hard or cohesive), obstructing root development, and have low values of exchangeable cations, with $\mathrm{Al}^{+3}$ dominating the exchange complex, as well as low levels of organic matter and available phosphorus (P) (Melo et al., 2010). The cultivation of grains in the state of Roraima is being developed in these soils, with a great increase of soybean and corn. The climatic characterization of the region according to the Köppen classification is type AW, tropical rainy, hot and humid, with annual average rainfall of $1.600 \mathrm{~mm}$, with dry period from October to March (Araújo et al., 2001).

\subsection{Measuring precipitation}

Rainfall precipitation was recorded daily, through the automatic meteorological station installed approximately $200 \mathrm{~m}$ from the experimental area. The experiment considered rainfall events separately if an event was separated by at least $6 \mathrm{~h}$ from another event, with maximum rain of $1.0 \mathrm{~mm}$. Rains were considered erosive if they were equal to or greater than $10.0 \mathrm{~mm}$, or equal to or greater than $6.0 \mathrm{~mm}$ in a period of less than 15 minutes, according to the criteria proposed by Wischmeier and Smith (1978), with modifications suggested by Carvalho et al. (1989). The duration of the rains was measured periodically at intervals of 24 hours, and was obtained using a rain gauge installed in the automatic station, considering the contact time from the beginning to the end of the precipitation (in hours or minutes). 
The monthly erosion rate and average rainfall was expressed by the $\mathrm{EI}_{30}$ index (Wischmeier and Smith, 1958) in the International System of Units - MJ mm ha ${ }^{-1} \mathrm{~h}^{-1}$ (Foster et al., 1981), obtained by the product of the total kinetic energy of rainfall (E - MJ ha-1) and the maximum intensity in 30 minutes $\left(\mathrm{I}_{30}-\mathrm{mm} \mathrm{h}^{-1}\right)$, according to Wischmeier and Smith (1958), and grouped by months. The kinetic energy of the rains was determined by Equation 1 of Wischmeier and Smith (1958), adjusted to the International System of Units by Foster et al. (1981).

$$
E c=0.119+0.0873 \log I p
$$

Where EC - is the kinetic energy, $\mathrm{MJ} \mathrm{ha}^{-1} \mathrm{~mm}^{-1}$ and Ip is the precipitation intensity $\left(\mathrm{mm} \mathrm{h}^{-1}\right)$.

The total kinetic energy of the individual erosive rain was obtained by the sum of the kinetic energy of each segment of the rain, while the maximum intensity in thirty minutes was obtained according to Equation 2, proposed by Carvalho et al. (1989):

$I_{30}=\frac{\left(\sum_{i=1}^{n} i_{n i} x t_{n i}\right)}{30}$

Where: $\mathrm{I}_{30}$ - is the rain intensity in 30 consecutive minutes $\left(\mathrm{mm} \mathrm{h}^{-1}\right)$; In - is the value for rain intensity of order $\mathrm{n}\left(\mathrm{mm} \mathrm{h}^{-1}\right)$, occurring within 30 minutes; Tn - is the period of occurrence of rain intensity of order $n$, occurring within 30 minutes.

After obtaining the maximum intensity within thirty minutes, the values were applied in Equation 3 to calculate the erosivity index $\left(\mathrm{EI}_{30}\right)$ of each precipitation. In turn, the monthly $\mathrm{EI}_{30}$ was obtained by the sum of the $\mathrm{EI}_{30}$ of each erosive precipitation that occurred in that month.

$E I_{30}=E C_{t} \times I_{30}$

Where: $\mathrm{EI}_{30}$ - is the erosion index of individual erosive rain, $\mathrm{MJ} \mathrm{mm} \mathrm{ha}^{-1} \mathrm{~h}^{-1}$ and $\mathrm{I}_{30}$ - is the maximum rainfall intensity in the period of 30 consecutive minutes, $\mathrm{mm} \mathrm{h}^{-1}$.

\subsection{Facilities of the experimental area}

The experimental design chosen was completely structured with five treatments (bare soil - BS, cowpea bean planting - CB, Brachiaria brizantha - BB, corn planting - CO and savanna - SN) and three replicates per treatment with collections over time. This experiment was carried out on a slope of $2 \%$ in blocks, positioned at the center of the experimental area, with dimensions of $2.0 \times 18.0 \mathrm{~m}\left(36 \mathrm{~m}^{2}\right)$ and spacing of $1.0 \mathrm{~m}$. The courts were flanked with galvanized zinc leaves $0.30 \mathrm{~m}$ high, imbedded $0.10 \mathrm{~m}$ in the ground to block the entrance and exit of the eroded material. At the lower ends of each block, $0.30 \mathrm{~m}$ wide galvanized steel plates were drilled into the ground, leaving $0.20 \mathrm{~m}$ above the surface.

PVC collector pipes $(100 \emptyset \mathrm{mm})$ were installed, coupled to the collecting tube and interconnected to two storage tanks with $200 \mathrm{~L}$ capacity each, whose function was the accumulation of water and sediments (Figure 1). The first interconnected tank served for water storage. At the end of each pipe exiting the block geo bags were placed to retain the sediments and release water and fine sediments (silt and clay). At the exit end of the first tank, a $25 \mathrm{~mm}$ PVC pipe connected it to the second tank with 10 sections of equal-flow outlets. Only one was used for collection in the second tank and the other was discarded, since it's function was simply to avoid overflow in the case of high precipitation. In the second tank, the water values obtained were multiplied by 10 for the final calculation of the losses that occurred, which added with the values of the first tank. 


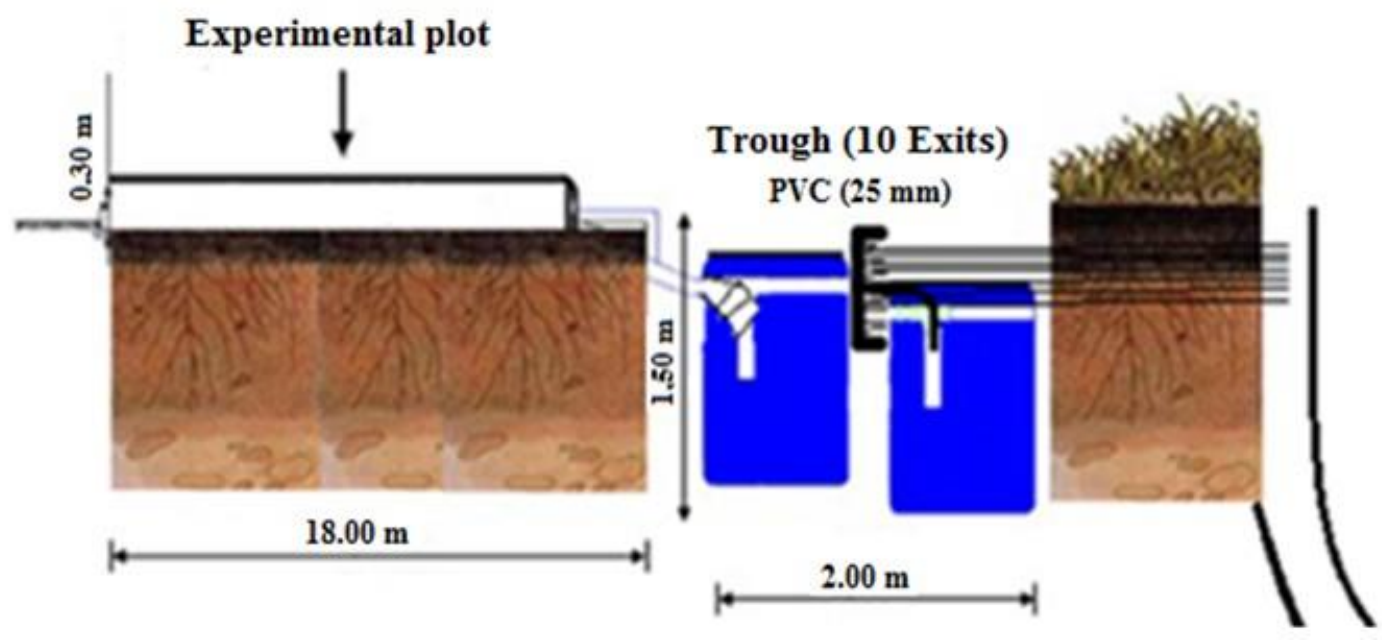

Figure 1. Representation of the experimental area with PVC collecting pipes, coupled to the collecting trough and interconnected to $200 \mathrm{~L}$ tanks.

The frequency of collection of soil for the quantification of losses of soil, water, organic carbon and nutrients ranged from one to two per day, depending on the occurence of each rain considered to have erosive potential. Rainfall characteristics were analyzed based on the records obtained each day at the automatic meteorological station installed near the experimental area, taking into account rainfall intensity and the kinetic energy of raindrops on the soil. This made it possible to calculate the erosive potential of each rain, expressed by the EI30 value (Bertoni and Lombardi Neto 2012).

After installing the collector blocks, conventional soil preparation was carried out with manual soil rotation by hoe and hoeing in all experimental plots, in addition to the plantings in the experimental area with the following treatments: 1- Brachiaria brizantha (BB); 2 - corn cultivation (CO); 3 - cowpea bean (CB); 4 - bare soil (BS) and 5 - natural savanna (SN).

The cultivated plots were fertilized according to the recommendations for each crop. For corn and brachiaria, fertilizer was applied in the proportion of $110 \mathrm{~kg} \mathrm{ha}^{-1}$ of $\mathrm{N}$, divided into two applications: the first 15 days after emergence, in the amount of $50 \mathrm{~kg} \mathrm{ha}^{-1}$ of $\mathrm{N}$; the second 35 days after emergence, with $60 \mathrm{~kg} \mathrm{ha}^{-1}$, in addition to $120 \mathrm{~kg} \mathrm{ha}^{-1}$ of $\mathrm{P}_{2} \mathrm{O}_{5}$ and $60 \mathrm{~kg} \mathrm{ha}^{-1}$ of $\mathrm{K}_{2} \mathrm{O}$ at planting. For cowpea, $80 \mathrm{~kg} \mathrm{ha}^{-1}$ of $\mathrm{P}_{2} \mathrm{O}_{5}$ and $60 \mathrm{~kg} \mathrm{ha}^{-1}$ of $\mathrm{K}_{2} \mathrm{O}$ were added to the soil, and the seeds were inoculated with strain BR 3267. At 90 days before planting, all experimental plots and treatments (BS and $\mathrm{SN}$ ) were corrected with dolomitic limestone according to liming recommendation for experimental area, equivalent to $2000 \mathrm{~kg} \mathrm{ha}^{-1}$. The fertilizers were applied to the soil, aiming to standardize the application in the planting area.

\subsection{Determination of soil and water losses}

Soil losses were determined by the direct method during the crop cycle, during the months of higher precipitation in the year of 2013, based on rainfall data from previous years.

Surface runoff, along with the sediments transported from the experimental plots, occurred through PVC pipes $(100 \mathrm{~mm})$ to a collection structure positioned at the lower-slope end of the experimental area. In this structure, the transported sediments were retained in the previously weighed filter (geotextile blanket), which allowed the collection of the coarsest soil particles transported (Silva et al., 2005a).

Considering that the blanket did not retain all the diameters of suspended soil particles in the runoff, at each data collection the volume of water in the storage drum was homogenized and an aliquot was taken to determine the amount of suspended soil that had passed by the filter. In this way the suspended material collected in a $500 \mathrm{ml}$ glass beaker were placed to dry in a forced circulation oven at $105^{\circ} \mathrm{C}$ until the water was totally evaporated. The acquired mass was 
later added to the mass of soil retained in the filter to total the loss of soil. The height of the water column drained to the collection tanks was measured using a one-meter long millimeter ruler placed in the center of each tank. The water volume of the tank was determined according to the height of the water slide and the diameter of each tank.

\subsection{Determination of nutrient and organic carbon losses}

Nutrient losses were determined during the rainy season with the highest precipitation in 2013, based on rainfall data from previous years. For each determination of the soil losses in the plots, soil samples were taken for quantification of organic $\mathrm{P}, \mathrm{K}, \mathrm{Ca}, \mathrm{Mg}$ and $\mathrm{C}$ (C-org) in the sediments. Thus, the amounts transported per area of each element were obtained through the chemical analyses of the dry sediments of each plot and the suspended material.

The total exchangeable contents of cations $\left(\mathrm{Ca}^{2+} \mathrm{e} \mathrm{Mg}^{2+}\right)$ were extracted in $\mathrm{KCl} 1 \mathrm{~mol} \mathrm{~L}^{-1}$ and titrated with EDTA (Embrapa, 2011). Phosphorus (P) and potassium (K) were extracted by Mehlich $^{-1}\left(\mathrm{H}_{2} \mathrm{SO}_{4} 0.0125 \mathrm{~mol} \mathrm{~L}^{-1}+\mathrm{HCl} 0.05 \mathrm{~mol} \mathrm{L^{-1 }}\right), \mathrm{P}$ being visible by UV spectrophotometry and $\mathrm{K}^{+}$by flame photometry (Embrapa 2011). C-org was determined by the modified Walkley and Black method (Yeomans and Bremner, 1988), based on the oxidation of organic matter by dichromate of potassium, with diphenylamine being used as an indicator (Embrapa, 2011).

\subsection{Statistical analysis}

The results obtained from losses of soil, water, nutrients and organic carbon in each replicate were submitted to analysis of variance (ANOVA), through the statistical program SISVAR (Ferreira, 2008), and were compared to the Tukey test at the 5\% probability level $(\mathrm{p}<0.05)$.

\section{RESULTS AND DISCUSSION}

\subsection{Loss of soil and water by surface runoff}

During the evaluation in June, the highest losses occurred in the treatment of bare soil (BS), with $302.61 \mathrm{~kg} \mathrm{ha}^{-1}$ month $^{-1}$ (Table 2). This was because BS did not present any type of cover, which allows the detachment and transport of soil after particle spattering caused by the impact of raindrops; these results are in agreement with those obtained by Bertol et al. (2007), Barros et al. (2009) and Panachuki et al. (2011). Another factor observed was the treatment of cowpea bean (CB) with $149.01 \mathrm{~kg} \mathrm{ha}^{-1}$ month $^{-1}$, which showed significant differences when compared to other treatments, a fact that may be related to the specific behavior of types of ground cover, or even spacing in relation to the structure of the plant during its initial vegetative cycle, thus providing greater soil losses in relation to the treatments of BB with $12.74 \mathrm{~kg} \mathrm{ha}^{-1}$ month $^{-1}$, CO with $81.52 \mathrm{~kg} \mathrm{ha}^{-1}$ month $^{-1}$ and SN with $8.07 \mathrm{~kg} \mathrm{ha}^{-1}$ month $^{-1}$ (Table 2). According to Cardoso et al. (2012), the groundcover plants' strains influence these losses; therefore, it is expected that a species with a high coverage index and biomass productivity will provide higher protection to the soil, reducing the impact of the raindrops on it as well as the surface runoff. Castro et al. (2011) and Cardoso et al. (2013) state that the crop coverage index is directly related to the development of plant and that should protect the soil from the beginning of the crop cycle. They recommend reduced spacing when the objective is rapid coverage of soil and phytomass production. In this way, the erosion rates can be reduced by increasing the ground cover. The presence of vegetation helps water retention in the soil and reduces the speed of the runoff (Lima et al., 2013), since the cover is a major factor on the dissipation of the kinetic energy of the raindrops (Guth, 2010). 
Table 2. Soil losses $\left(\mathrm{kg} \mathrm{ha}^{-1}\right)$ for treatments using bare soil (BS), plantation of cowpea bean (CB), planting with Brachiaria brizantha (BB), corn (CO) and savanna).

\begin{tabular}{|c|c|c|c|c|c|}
\hline & June & July & August & & \\
\hline Treatment & \multicolumn{3}{|c|}{ Soil Losses $\left(\mathrm{kg} \mathrm{ha}^{-1}\right.$ month $\left.^{-1}\right)$} & Total & Average \\
\hline BS & $302.61 \mathrm{a}$ & $301.92 \mathrm{a}$ & $460.74 \mathrm{a}$ & $1,065.27$ & 355.09 \\
\hline $\mathrm{CB}$ & $149.01 \mathrm{~b}$ & $99.80 \mathrm{~b}$ & $59.55 \mathrm{~b}$ & 308.36 & 102.79 \\
\hline BB & $12.74 \mathrm{c}$ & $0.00 \mathrm{c}$ & $0.00 \mathrm{~b}$ & 12.74 & 4.25 \\
\hline $\mathrm{CO}$ & $81.52 \mathrm{bc}$ & $5.83 \mathrm{c}$ & $44.91 \mathrm{~b}$ & 132.26 & 44.09 \\
\hline $\mathrm{SN}$ & $8.07 \mathrm{c}$ & $3.30 \mathrm{c}$ & $11.00 \mathrm{~b}$ & 22.37 & 7.46 \\
\hline $\mathrm{CV}(\%)$ & 28.34 & 139.55 & 72.57 & & \\
\hline Precipitation of erosive rainfall (mm) & 86.8 & 107.4 & 177.8 & 372 & 124 \\
\hline $\mathrm{EI}_{30}\left(\mathrm{MJ} \mathrm{mm}^{-1} \mathrm{ha}^{-1} \mathrm{~h}^{-1}\right)$ & 976.63 & 1476.62 & 2305.65 & 4758.90 & 1586.30 \\
\hline Kinetic Energy $\left(\mathrm{MJ} \mathrm{mm} \mathrm{m}^{-1} \mathrm{month}^{-1}\right)$ & 0.63076 & 0.94562 & 1.22993 & 2.80630 & 0.93543 \\
\hline
\end{tabular}

The values followed by the same letter in the columns do not differ according to the Tukey test at $0.05 \%$ probability.

When soil losses were evaluated during July, it was observed that the treatments BS, CB, $\mathrm{BB}, \mathrm{CO}$ and $\mathrm{SN}$ followed the same statistical trend of the previous month, but with lower losses. This may be related to the occurrence of low intensity rains, in addition to a scenario of better crop development presented during the month of July. Santos et al. (2010), evaluating the intense rains related to water erosion, found that the aspects that interfere the most with soil erosion are intensity, duration, frequency and erosivity. As other works highlight, rainfall erosivity is considered one of the most important factors to estimate soil losses (Shamshad et al., 2008).

During the evaluation in August, it was observed that the highest soil losses occurred in the treatment of BS with $460.74 \mathrm{~kg} \mathrm{ha}^{-1}$ month $^{-1}$, while the other treatments $\mathrm{CB}, \mathrm{BB}, \mathrm{CO}$ and SN did not show significant differences ( 0.05 scored on Tukey test). The high value of soil losses for the BS treatment is related to heavy rainfalls during the period and to the high degree of superficial surface sealing due to the absence of groundcover plants within the respective treatments. The results are in agreement with the studies of Bertol et al. (2007), which demonstrate that conventional preparation of less-protected soils provides a greater rate of decrease of infiltration reflex of superficial ground sealing. In this same context, other studies confirm the results obtained, where they affirm that after several months of rainfall, the soil is more saturated and the water infiltration rate decreases, with increased surface runoff, and high losses of soil and water (Carvalho et al., 2012; Oliveira et al., 2013).

The BB, SN and CO treatments have been shown to better protect the soil when compared to the $\mathrm{BS}$ and $\mathrm{CB}$ treatments, as they promoted greater soil coverage due to the greater green biomass and enhanced root development. In this regard, the results observed corroborate the studies of Soane et al. (2012) and Lima et al. (2013), which found that erosion rates can be reduced with the increase of groundcover plants, since the presence of vegetation aids the retention of water and reduces the speed of surface runoff. Cover is fundamental to the dissipation of the kinetic energy of raindrops (Guth, 2010).

The erosivity index data $\left(\mathrm{EI}_{30}\right)$ of evaluated months (Table 2$)$ was obtained by method proposed by Wischmeier and Smith (1958), which is recognized world-wide as the R factor of USLE, and recommended for use in several regions worldwide, including in Brazil (North: Barros et al., 2009; South: Bertol et al., 2007; Cogo et al., 2003; Guadagnin et al., 2005; Marioti et al., 2013; Oliveira et al., 2015; Southeast: Cardoso et al., 2012; Dias et al., 2013; Pires et al., 2006; Silva et al., 2005a Midlewest: Leite et al., 2009; Panachuki et al., 2011; and Northeast: Albuquerque et al., 1998). 
Regarding the total of water losses that occurred during the month of June, it was observed that the studied BS, CB and BB treatments did not differ statistically among themselves, using the Tukey test at a 0.05 probability. Irregular distribution and low rainfall can explain the low values of water losses (Table 3).

During July, due to the increased rainfall regime, it was possible to diagnose higher water losses in the treatment of BS, with $253.92 \mathrm{~m}^{3} \mathrm{ha}^{-1} \mathrm{month}^{-1}$ (Table 3), statistically superior to the other treatments under study. Similar results were obtained by Panachuki et al. (2011) and Marioti et al. (2013). It was also observed that the CB treatment of $134.47 \mathrm{~m}^{3} \mathrm{ha}^{-1} \mathrm{month}^{-1}$ presented higher water losses when compared to treatments of $\mathrm{BB}, \mathrm{CO}$, and $\mathrm{SN}$ (Table 3).

Table 3. Water losses $\left(\mathrm{m}^{3} \mathrm{ha}^{-1}\right)$ for treatments, bare soil (BS), cowpea (CB), Brachiaria brizantha (BB), corn (CO) and savanna (SN).

\begin{tabular}{lccccc}
\hline \multicolumn{1}{c}{ June } & July & August & & \\
\hline Treatment & Water losses $\left(\mathrm{m}^{3} \mathrm{ha}^{-1}\right.$ & month $\left.^{-1}\right)$ & Total & Average \\
\hline BS & $69.32 \mathrm{a}$ & $253.92 \mathrm{a}$ & $599.43 \mathrm{a}$ & 922.67 & 307.56 \\
$\mathrm{CB}$ & $57.89 \mathrm{a}$ & $134.47 \mathrm{~b}$ & $284.70 \mathrm{~b}$ & 477.06 & 159.02 \\
$\mathrm{BB}$ & $47.47 \mathrm{ab}$ & $0.39 \mathrm{~d}$ & $0.00 \mathrm{~d}$ & 47.86 & 15.95 \\
$\mathrm{CO}$ & $15.52 \mathrm{c}$ & $20.65 \mathrm{~d}$ & $88.86 \mathrm{~cd}$ & 125.03 & 41.68 \\
$\mathrm{SN}$ & $24.44 \mathrm{bc}$ & $49.70 \mathrm{c}$ & $217.79 \mathrm{bc}$ & 291.93 & 97.31 \\
$\mathrm{CV}(\%)$ & 21.60 & 9.10 & 22.10 & & \\
\hline Precipitation of erosive rainfall $(\mathrm{mm})$ & 86.8 & 107.4 & 177.8 & 372 & 124 \\
EI $_{30}\left(\mathrm{MJ} \mathrm{mm}\right.$ ma $\left.^{-1} \mathrm{~h}^{-1}\right)$ & 976.63 & 1476.62 & 2305.65 & 4758.90 & 1586.30 \\
Kinetic Energy $\left(\mathrm{MJ} \mathrm{mm}^{-1}\right.$ month $\left.^{-1}\right)$ & 0.63076 & 0.94562 & 1.22993 & 2.80630 & 0.93543 \\
\hline
\end{tabular}

The values followed by the same letter in the columns do not differ according to the Tukey test at $0.05 \%$ probability.

In the month of August, the BS treatment of $599.43 \mathrm{~m}^{3} \mathrm{ha}^{-1}$ month $^{-1}$ presented higher water losses, followed by CB treatments of $284.70 \mathrm{~m}^{3} \mathrm{ha}^{-1}$ month $^{-1}$ and $\mathrm{SN}$ of $217.79 \mathrm{~m}^{3} \mathrm{ha}^{-1} \mathrm{month}^{-1}$. The other treatments under study followed the same trend of July, where the $\mathrm{BB}$ and $\mathrm{CO}$ treatments did not present significant differences (Table 3).

By establishing a comparative analysis between soil and water losses within all treatments during the three-month evaluation period and based on the total precipitation of collected erosive rains, it was possible to verify that the $\mathrm{BB}, \mathrm{CO}$ and $\mathrm{SN}$ treatments were more effective in reducing soil and water losses in all evaluated months (Table 2 and 3). For the BB treatment, this fact is attributed to the root system of the grasses being of the fasciculated type, acting as an important restructuring agent of the raindrops, according to the results obtained by Cardoso et al. (2012). The occurrence of lower sediment losses in the BB and CO treatments can be explained by the fact that both crops present more protectionist features due to the greater ground coverage and faster development that delays the beginning of the surface runoff. These results are in accordance with those obtained by Marioti et al. (2013). For the SN treatment, the flow was softened due to the presence of existing natural vegetation, something that directly contributed to the protection against the impact of rain drops. In this condition the soil presented a greater infiltration capacity and has a lower runoff rate. Similar results were found by Barros et al. (2009) working in Oxisol and Ultisol of Roraima savanna. According to Cabanêz et al. (2011), surface runoff only begins when the soil exceeds its water infiltration capacity and is directly related to the intensity of the precipitation.

After data analysis of the precipitation of erosive rains, with soil $\left(\mathrm{kg} \mathrm{ha}^{-1}\right)$ and water losses $\left(\mathrm{m}^{3} \mathrm{ha}^{-1}\right)$, it was observed that the losses remained high in the BS treatment, while the other treatments showed some variations; e.g., the BB treatment reduced groundcover (Table 2 and 
3). It was observed that the precipitation which occurred during the month of August generated a larger flood volume, promoting significant soil drag in all treatments except for the BB treatment, where the flood was attenuated by the vegetation coverage.

\subsection{Loss of nutrient and organic carbon in sediments by flash flood}

After the evaluations carried out in June, it was observed that for the $\mathrm{Ca}^{2+}$ nutrient the greatest losses occurred in HR treatment with $0.206 \mathrm{~kg} \mathrm{ha}^{-1}$, differing statistically from the other treatments (Table 4). The lowest losses of these nutrients occurred in the BB treatment, with $0.013 \mathrm{~kg} \mathrm{ha}^{-1}$ and SN with $0.004 \mathrm{~kg} \mathrm{ha}^{-1}$, probably due to the presence of foliar cover to minimize nutrient losses in the sediments of the flood, which was also observed by other authors like Barros et al. (2009), Ekholm and Lehtoranta (2012) and Sousa et al. (2012), where nutrient losses can occur associated with transport by the flow or adsorbed by the sediments carried on the flood.

Table 4. Nutrient loss and organic carbon $\left(\mathrm{kg} \mathrm{ha}^{-1}\right)$ values for treatments, bare soil (BS), cowpea bean $(\mathrm{CB})$, Brachiaria brizantha $(\mathrm{BB})$, corn $(\mathrm{CO})$ and savanna $(\mathrm{SN})$.

\begin{tabular}{|c|c|c|c|c|c|c|c|}
\hline \multirow{3}{*}{ Treatment } & \multirow{3}{*}{$\begin{array}{c}\mathbf{E I}_{\mathbf{3 0}} \\
\left(\mathbf{M J} \mathbf{~ m m}^{-\mathbf{1}} \mathbf{h a}^{-\mathbf{1}} \mathbf{h}^{-\mathbf{1}}\right) \\
976.63\end{array}$} & \multirow{2}{*}{\multicolumn{2}{|c|}{$\begin{array}{l}\text { Kinetic energy } \\
\text { (MJ } \text { mm}^{-1} \text { month) }\end{array}$}} & \multicolumn{4}{|c|}{$\begin{array}{c}\text { Loss of nutrient and organic carbon in } \\
\text { sediments by flash flood }\end{array}$} \\
\hline & & & & \multicolumn{4}{|c|}{ June (kg ha $\left.{ }^{-1}\right)$} \\
\hline & & 0.63076 & $\mathrm{Ca}^{2+}$ & $\mathrm{Mg}^{2+}$ & $\mathrm{P}$ & $\mathrm{K}^{+}$ & $\mathrm{CO}$ \\
\hline BS & & & $0.103 \mathrm{~b}$ & $0.270 \mathrm{a}$ & $0.018 \mathrm{c}$ & $0.003 \mathrm{ab}$ & $1.678 \mathrm{a}$ \\
\hline CB & & & $0,206 \mathrm{a}$ & $0.161 \mathrm{~b}$ & $0.248 \mathrm{a}$ & $0.004 \mathrm{a}$ & $0.626 \mathrm{~b}$ \\
\hline BB & & & $0.013 \mathrm{c}$ & $0.010 \mathrm{~d}$ & $0.092 \mathrm{~b}$ & $0.000 \mathrm{c}$ & $0.082 \mathrm{~b}$ \\
\hline $\mathrm{CO}$ & & & $0.114 b$ & $0.092 \mathrm{c}$ & $0.051 \mathrm{bc}$ & $0.001 \mathrm{bc}$ & $0.463 \mathrm{~b}$ \\
\hline $\mathbf{S N}$ & & & $0.004 \mathrm{c}$ & $0.003 \mathrm{~d}$ & $0.002 \mathrm{c}$ & $0.000 \mathrm{c}$ & $0.034 \mathrm{~b}$ \\
\hline Average & & & 0.088 & 0.107 & 0.107 & 0.0016 & 0.577 \\
\hline CV $(\%)$ & & & 25.80 & 17.86 & 28.90 & 36.51 & 37.39 \\
\hline Treatment & $\begin{array}{c}\text { EI30 } \\
\left(\mathbf{M J} \mathbf{m m}^{-1} \mathbf{h a}^{-1} \mathbf{h}^{-1}\right)\end{array}$ & \multicolumn{2}{|c|}{$\begin{array}{c}\text { Kinetic energy } \\
\text { (MJ } \text { mm}^{-1} \text { month) }\end{array}$} & \multicolumn{4}{|c|}{ July (kg ha' $\left.{ }^{-1}\right)$} \\
\hline & 1.476 .62 & 0.94562 & $\mathrm{Ca}^{2+}$ & $\mathrm{Mg}^{2+}$ & $\mathrm{P}$ & $\mathrm{K}^{+}$ & $\mathrm{CO}$ \\
\hline BS & & & $0.098 \mathrm{a}$ & $0.076 \mathrm{ab}$ & $0.013 \mathrm{~b}$ & $0.002 \mathrm{ab}$ & $0.860 \mathrm{a}$ \\
\hline CB & & & $0.154 \mathrm{a}$ & $0.116 \mathrm{a}$ & $0.185 \mathrm{a}$ & $0.006 \mathrm{a}$ & $0.566 \mathrm{~b}$ \\
\hline BB & & & $0.000 \mathrm{~b}$ & $0.000 \mathrm{c}$ & $0.000 \mathrm{c}$ & $0.000 \mathrm{c}$ & $0.000 \mathrm{c}$ \\
\hline $\mathrm{CO}$ & & & $0.005 \mathrm{~b}$ & $0.006 \mathrm{bc}$ & $0.006 \mathrm{bc}$ & $0.0004 \mathrm{c}$ & $0.028 \mathrm{c}$ \\
\hline $\mathbf{S N}$ & & & $0.003 \mathrm{~b}$ & $0.003 \mathrm{c}$ & $0.003 \mathrm{c}$ & $0.0001 \mathrm{c}$ & $0.012 \mathrm{c}$ \\
\hline Average & & & 0.052 & 0.040 & 0.065 & 0.0017 & 0.293 \\
\hline CV (\%) & & & 62.00 & 63.04 & 7.18 & 69.15 & 30.34 \\
\hline Treatment & $\begin{array}{c}\text { EI }_{30} \\
\left(\mathrm{MJ} \mathrm{mm}^{-1} \mathbf{h a}^{-1} \mathbf{h}^{-1}\right)\end{array}$ & \multicolumn{2}{|c|}{$\begin{array}{c}\text { Kinetic energy } \\
\left(\mathrm{MJ} \mathrm{mm}^{-1} \text { month }\right)\end{array}$} & \multicolumn{4}{|c|}{ August (kg ha-1) } \\
\hline & 2.305 .65 & 1.22993 & $\mathrm{Ca}^{2+}$ & $\mathrm{Mg}^{2+}$ & $\mathrm{P}$ & $\mathrm{K}^{+}$ & $\mathrm{CO}$ \\
\hline BS & & & $0.143 \mathrm{a}$ & $0.155 \mathrm{a}$ & $0.049 \mathrm{ab}$ & $0.003 \mathrm{a}$ & $1.875 \mathrm{a}$ \\
\hline CB & & & $0.085 \mathrm{ab}$ & $0.068 \mathrm{~b}$ & $0.171 \mathrm{a}$ & $0.004 \mathrm{a}$ & $0.225 \mathrm{~b}$ \\
\hline BB & & & $0.000 \mathrm{c}$ & $0.000 \mathrm{~b}$ & $0.000 \mathrm{c}$ & $0.000 \mathrm{~b}$ & $0.000 \mathrm{~b}$ \\
\hline $\mathrm{CO}$ & & & $0.025 b c$ & $0.030 \mathrm{~b}$ & $0.035 \mathrm{ab}$ & $0.0014 \mathrm{ab}$ & $0.090 \mathrm{~b}$ \\
\hline SN & & & $0.007 \mathrm{c}$ & $0.006 \mathrm{~b}$ & $0.006 \mathrm{c}$ & $0.005 \mathrm{ab}$ & $0.068 \mathrm{~b}$ \\
\hline Average & & & 0.052 & 0.052 & 0.052 & 0.0027 & 0.452 \\
\hline CV $(\%)$ & & & 45.99 & 57.99 & 108.80 & 66.90 & 24.17 \\
\hline
\end{tabular}

Values followed by the same letter in the columns do not differ significantly from each other, according to the Tukey test at $0.05 \%$ probability.

When $\mathrm{Mg}^{2+}$ losses were evaluated, the highest losses were observed in the treatment of BS with $0.270 \mathrm{~kg} \mathrm{ha}^{-1}$ followed by the treatment of $\mathrm{CB}$ with $0.161 \mathrm{~kg} \mathrm{ha}^{-1}$; similar results were 
obtained by (Dias et al., 2013). For the CB treatment, the growth of the plant during its vegetative cycle might have influenced the losses of nutrients in this system, considering studies evaluating cover plants in the control of water erosion done by Dias et al. (2013), which affirm that the speed at which a given plant covers the soil surface greatly influences the erosion process. This is due to the initial period of crop growth, when the soil surface is unprotected and more susceptible to erosion. In the same sense, Cardoso et al. (2012) state that the more intertwined the aerial part of the plants, the lower are the losses due to erosion.

The lower losses of $\mathrm{Mg}^{2+}$ followed the same trend of the $\mathrm{Ca}^{2+}$ nutrient, since the BB with $0.010 \mathrm{~kg} \mathrm{ha}^{-1}$ and SN with $0.003 \mathrm{~kg} \mathrm{ha}^{-1}$ treatments were the ones with the lowest losses of this nutrient. For the nutrient $\mathrm{P}$, the highest losses occurred in the treatment of $\mathrm{CB}$ with $0.248 \mathrm{~kg} \mathrm{ha}^{-1}$, followed by the BB treatment with $0.092 \mathrm{~kg} \mathrm{ha}^{-1}$ and $\mathrm{CO}$ with $0.051 \mathrm{~kg} \mathrm{ha}^{-1}$ (Table 4). $\mathrm{P}$ losses in the treatments follow the sequence of $\mathrm{CB}>\mathrm{BB}>\mathrm{CO}>\mathrm{SN}>\mathrm{BS}$. In regards to phosphorus loss, it can be said that it is mainly associated with small particles of the mineral fraction (clay) and organic matter, which are preferably transported by the surface runoff. The highest losses of $\mathrm{K}^{+}$were observed within the treatments with $0.004 \mathrm{~kg} \mathrm{ha}^{-1}$ and BS with $0.003 \mathrm{~kg} \mathrm{ha}^{-1}$. Studies have shown that $\mathrm{K}^{+}$, due to its lower retention by soil constituents, facilitates transport by water from the runoff, corroborating works by Silva et al. (2005a). Aguiar et al. (2006) found similar results and stated that, in general, high loss of $\mathrm{K}^{+}$may occur due to its high solubility, which facilitates transport by water. As with phosphorus, the loss of soil potassium by water erosion is more associated with sediment (Cogo et al., 2003).

After analyzing the organic carbon losses in June, it was observed that the losses were higher in the BS treatment, with $1.678 \mathrm{~kg} \mathrm{ha}^{-1}$; the other treatments $\mathrm{CB}, \mathrm{BB}, \mathrm{CO}$ and $\mathrm{SN}$ did not present significant differences (Table 4). The high organic carbon losses in BS is justified by studies demonstrating that colloidal fraction and organic matter are the first components to be removed by water erosion, due to its low density (Silva et al., 2005a).

When the $\mathrm{Ca}^{2+}$ losses were evaluated in the month of July, it was possible to observe that the highest losses occurred in the $\mathrm{CB}$ treatments, with $0.154 \mathrm{~kg} \mathrm{ha}^{-1}$, and $\mathrm{BS}$, with $0.098 \mathrm{~kg} \mathrm{ha}^{-1}$. Both treatments did not present significant differences. CO and SN did not present significant differences between them by the Tukey test at the 0.05 probability level. $\mathrm{Mg}^{2+}$ losses in the month of July followed the $\mathrm{Ca}^{2+}$ trend, with the highest losses occurring in the CB treatments, with $0.116 \mathrm{~kg} \mathrm{ha}^{-1}$, and BS, with $0.076 \mathrm{~kg} \mathrm{ha}^{-1}$. According to Cogo et al. (2003) and Sousa et al. (2012), soil calcium and magnesium are removed by the same process during water erosion, mainly adsorbed to its solid particles. Both $\mathrm{Ca}^{2+}$ and $\mathrm{Mg}^{2+}$ are easily leachable (Silva et al., 2005b; Cardoso et al., 2012). In view of the probable exposure to $\mathrm{Ca}^{2+}$ and $\mathrm{Mg}^{2+}$ losses, it is associated with the high soil losses that occurred in the treatments of BS and $\mathrm{CB}$ during the months evaluated.

For P losses, it was possible to observe that the results followed the same trend of the evaluations carried out in June, where it presented higher losses for the treatment of CB with $0.185 \mathrm{~kg} \mathrm{ha}^{-1}$; thus, the high content of this nutrient may be related to its natural selectivity, because $\mathrm{P}$ is associated mainly with smaller particles of the mineral fraction (clay) and organic matter, which are preferably transported by the surface runoff. For the nutrient $\mathrm{K}^{+}$, it was observed that the highest losses occurred in the $\mathrm{CB}$ treatment with $0.006 \mathrm{~kg} \mathrm{ha}^{-1}$ and BS with $0.002 \mathrm{~kg} \mathrm{ha}^{-1}$, but the treatments in $\mathrm{BB}, \mathrm{CO}$ and $\mathrm{SN}$ did not present significant differences between them. These results concerning the losses of $\mathrm{P}$ and $\mathrm{K}^{+}$, which occurred in July, can be justified based on other studies, which indicate that the application of fertilizers in crops over a long period of time tends to increase the concentration of P and K (Schick et al., 2000). This generates increase in the concentrations of these nutrients in both the water and the sediments present in flooding (Guadagnin et al., 2005). Another factor that may have contributed to these losses in the CB treatment may be related to the different behavior of the foliar cover types, 
adopted spacing or even in relation to the structure of the plant during its vegetative cycle, which resulted in higher soil losses in comparison to the BB, CO and SN treatments.

When the losses of organic carbon were analyzed in July, it was observed that the highest carbon losses occurred in the BS treatment with $0.860 \mathrm{~kg} \mathrm{ha}^{-1}$, followed by the CB treatment with $0.566 \mathrm{~kg} \mathrm{ha}^{-1}$, showing the same behavior of the month of June for both treatments. However, the BB, CO and SN treatments did not present significant differences between them. For the $\mathrm{BB}$ and $\mathrm{CO}$ treatments, the results may be justifiable considering that both treatments were already established and at the end of the cycle, providing greater leaf coverage in relation to the other treatments. These results corroborate those found by Ekholm and Lehtoranta (2012). Spohr et al. (2009) and Dechen et al. (2015), which state that a higher percentage of vegetation cover, soil surface roughness and crop evapotranspiration improve soil water infiltration rates and, consequently, lower the losses by runoff. However, the SN treatment can be justified based on Albuquerque et al. (2005), which highlight that soils under native vegetation are usually in a better aggregation state and have stable organic matter content.

The evaluations carried out in August show no significant differences in $\mathrm{Ca}^{2+}$ losses between the BS treatment with $0.143 \mathrm{~kg} \mathrm{ha}^{-1}$ and the CB treatment with $0.085 \mathrm{~kg} \mathrm{ha}^{-1}$. When the $\mathrm{Mg}^{2+}$ losses were considered, it was possible to observe that the highest losses occurred in the BS treatment with $0.155 \mathrm{~kg} \mathrm{ha}^{-1}$ followed by the $\mathrm{CB}, \mathrm{BB}, \mathrm{CO}$ and $\mathrm{SN}$ treatments, so that they did not present significant differences among themselves by the Tukey test at 0.05 probability. For the nutrient $\mathrm{P}$, it was observed that $\mathrm{CB}$ treatments with $0.171 \mathrm{~kg} \mathrm{ha}^{-1}$, BS with $0.049 \mathrm{~kg} \mathrm{ha}^{-1}$ and $\mathrm{CO}$ with $0.035 \mathrm{~kg} \mathrm{ha}^{-1}$ did not show significant differences between them. When the $\mathrm{K}^{+}$losses were evaluated, there were no differences between $\mathrm{BS}, \mathrm{CB}, \mathrm{BB}$ and $\mathrm{CO}$ treatments, with the exception of the BB treatment, a fact that may have occurred due to the respective treatment being at the end of the vegetative cycle, something which provided sufficient leaf cover to minimize losses of this nutrient.

When evaluating the losses of organic carbon during August, it was observed that the greatest losses occurred for the treatment of BS with $1.875 \mathrm{~kg} \mathrm{ha}^{-1}$; there was no significant difference in the other treatments of $\mathrm{CB}, \mathrm{BB}, \mathrm{CO}$ or $\mathrm{SN}$. These results are mainly attributed to the physical barrier provided by the groundcover plants, reducing the kinetic energy of sediment transport in the runoff, making it difficult to break the aggregates. In the case of bare soil, the effect was inverted due to the absence of protection of the vegetal cover, which obviously provided greater losses of organic carbon. The results evidenced the need to adopt conservation practices that reduce water erosion, maintaining the organic fraction of soil, since it is important in maintenance of soil structure, moisture retention and cation exchange capacity, among other attributes, according to Silva et al. (2005a), mainly in the savanna soils of northern Amazonia.

\section{CONCLUSIONS}

1. The treatment of bare soil (BS), followed by the cultivated cowpea bean (CB) treatment, showed higher losses of soil, water, nutrients and organic carbon.

2. The highest losses of soil, water, nutrients and organic carbon in the treatment of bare soil (BS) occurred during the period of greatest erosivity, but for treatments of $\mathrm{CB}, \mathrm{BB}$ and $\mathrm{CO}$ it occurred during the establishment of the crop, in view of the lower soil cover.

3. Soils cultivated with Brachiaria brizantha - BB, corn - CO and the area with Savana Natural - SN, were more efficient in reducing soil and water losses during all months evaluated.

4. The plant covering produced by the treatments $\mathrm{SN}, \mathrm{BB}$ and $\mathrm{CO}$ acted to reduce the harmful effects of erosion, minimizing the losses of nutrients and organic carbon, differently from what happened in the bare soil (BS) treatment.

\section{IPABH}




\section{ACKNOWLEDGMENTS}

The authors would like to thank CAPES (Coordination of Improvement of Higher Level Personnel) for the scholarship granted to the first author's Master Degree in the Graduate Program in Agronomy (POSAGRO/UFRR).

\section{REFERENCES}

AGUIAR, M. I.; MAIA, S. M. F.; OLIVEIRA, T. S.; MENDONÇA, E. S.; ARAÚJO FILHO, J. A. Perdas de solo, água e nutrientes em sistemas agroflorestais no município de Sobral, CE. Revista Ciência Agronômica, v. 37, p. 270-278, 2006.

ALBUQUERQUE, A. W. et al. Parâmetros erosividade da chuva e da enxurrada correlacionados com as perdas de solo de um solo Bruno Não Cálcico de Sumé - PB. Revista Brasileira de Ciência do Solo, v. 22, n. 4, p. 743-749, 1998. http://dx.doi.org/10.1590/S0100-06831998000400020

ALBUQUERQUE, J. A.; ARGENTON, J.; BAYER, C.; WILDNER, L. P.; KUNTZE, M. A. G. Relação de atributos do solo com a agregação de um Latossolo Vermelho sob sistemas de preparo e plantas de verão para cobertura do solo. Revista Brasileira de Ciência do Solo, Viçosa, v. 29, n. 3, p. 415-424, 2005. http://dx.doi.org/10.1590/S010006832005000300012

ARAÚJO, W. F.; ANDRADE JÚNIOR, A. S.; MEDEIROS, R. D.; SAMPAIO, R. A. Precipitação pluviométrica mensal provável em Boa Vista, Estado de Roraima, Brasil. Revista Brasileira de Engenharia Agrícola e Ambiental, v. 5, n. 3, p. 563-567, 2001.

BARBOSA, R. I.; FEARNSIDE, P. M. Erosão do Solo na Amazônia: estudo de caso na região do apiaú, Roraima, Brasil. Acta Amazônica. v. 30, n. 4, p. 601-613, 2000. http://dx.doi.org/10.1590/1809-43922000304613

BARROS, L. S.; VALE JUNIOR, J. F.; SCHAEFER, C. E. G. R.; MOURÃO JUNIOR, M. Perdas de solo e água em plantio de Acacia mangium wild e savana em Roraima, norte da Amazônia. Revista Brasileira de Ciência do Solo, v. 33, n. 2, p. 447-454, 2009. http://dx.doi.org/10.1590/S0100-06832009000200022

BENEDETTI, U. G.; VALE JUNIOR, J. F.; SCHAEFER, C. E. G. R.; MELO, V. F.; UCHÔA, S. C. P. Gênese, química e mineralogia de solos derivados de sedimentos pliopleitocênicos e de rochas vulcânicas básicas em Roraima, norte Amazônico. Revista Brasileira de Ciência do Solo, v. 35, n. 1, p. 299-312, 2011. http://dx.doi.org/10.1590/S010006832011000200002

BERTOL, I.; COGO, N. P.; SCHICK, J.; GUADAGNIN, J. C.; AMARAL, A. J. Aspectos financeiros relacionados às perdas de nutrientes por erosão hídrica em diferentes sistemas de manejo do solo. Revista Brasileira de Ciência do Solo, v. 31, n. 1, p. 133-142, 2007. http://dx.doi.org/10.1590/S0100-06832007000100014

BERTONI, J.; LOMBARDI NETO, F. Conservação do solo. 8. ed. São Paulo: Ícone, 2012.

CABANÊZ, P. A.; FERRARI, J. L.; PAULA, M. F.; CABANÊZ, P. A. Precipitação efetiva: uma perspectiva para os estudos em Agroecologia. Revista Verde, v. 6, n. 5, p. 15-24, 2011. 
CARDOSO, D. P.; SILVA, M. L. N.; CARVALHO, G. J.; FREITAS, D. A. F.; AVANZI, J. C. Plantas de cobertura no controle das perdas de solo, água e nutrientes por erosão hídrica. Revista Brasileira de Engenharia Agrícola e Ambiental, v. 16, n. 6, p. 632-638, 2012. http://dx.doi.org/10.1590/S1415-43662012000600007

CARDOSO, D. P.; CARVALHO, G. J. SILVA, M. L. N.; FREITAS, D. A. F.; AVANZI, J. C. Atributos fitotécnicos de plantas de cobertura para a proteção do solo. Revista Verde, v. 8, n. 1, p. 19-24, 2013.

CARVAlHO, M. A. R.; MIRANDA, J. H.; DUARTE, S. N; CARVAlHO, L. C. C. Escoamento superficial na interação: cobertura vegetal e práticas de controle de erosão. Engenharia Agrícola, v. 32, n. 6, p. 1116-1125, 2012. http://dx.doi.org/10.1590/S010069162012000600013

CARVALHO, M. P.; LOMBARDI NETO, F.; VASQUES FILHO, J.; CATANEO, A. İndices de erosividade da chuva correlacionada com as perdas de um Podzólico Vermelho-amarelo eutrófico textura argilosa/muito argilosa de Mococa (SP): Primeira aproximação do fator erodibilidade dos solos. Revista Brasileira de Ciência do Solo, v. 13, n. 2, p. 237-242, 1989.

CASTRO, N. E. A.; SILVA, M. L. N.; FREITAS, D. A. F.; CARVALO, G. J.; MARQUES, R. M.; GONTIJO NETO, G. F. Plantas de cobertura no controle da erosão hídrica sob chuvas naturais. Bioscience Journal, v. 27, n. 5, p. 775-785, 2011.

COGO, N. P.; LEVIEN, R.; SCHWARZ, R. A. Perdas de solo e água por erosão hídrica influenciadas por métodos de preparo, classes de declive e níveis de fertilidade do solo. Revista Brasileira de Ciência do Solo, v. 27, n. 4, p. 743-753, 2003. http://dx.doi.org/10.1590/S0100-06832003000400019

CUNHA, J. M.; GAIO, D. C.; CAMPOS, M. C. C.; SOARES, M. D. R; SILVA, D. M. P; LIMA, A. F. L. Atributos físicos e estoque de carbono do solo em áreas de Terra Preta Arqueológica da Amazônia. Revista Ambiente \& Água. v. 12, n. 2, p. 263-281, 2017.

DECHEN, S. C. F.; TElleS, T. S.; GUIMARAES, M. F.; MARIA, I. C. Perdas e custos associados à erosão hídrica em função de taxas de cobertura do solo. Bragantia, v. 74, n. 2, p. 224-233, 2015. http://dx.doi.org/10.1590/1678-4499.0363

DIAS, A. C.; SILVA, M. L. N.; FREITAS, D. A. F.; BATISTA, P. V. G.; CURI, N.; CARVALHO, G. J. Soil cover plants on water erosion control in the South of Minas Gerais. Ciência e Agrotecnologia, v. 37, n. 5, p. 410-418, 2013. http://dx.doi.org/10.1590/S1413-70542013000500004

EMPRESA BRASILEIRA DE PESQUISA AGROPECUÁRIA - EMBRAPA. Manual de métodos de análise de solos. 2. ed. Rio de Janeiro: Embrapa Solos, 2011. 225 p.

EMPRESA BRASILEIRA DE PESQUISA AGROPECUÁRIA - EMBRAPA. Centro Nacional de Pesquisa de Solos. Sistema brasileiro de classificação de solos. 3. ed. Rio de Janeiro: Embrapa Solos, 2013. 353p.

EKHOLM, P.; LEHTORANTA, J. Does control of soil erosion inhibit aquatic eutrophication? Journal of Environmental Management, v. 93, p. 140-146, 2012. http://dx.doi.org/10.1016/j.jenvman.2011.09.010 
FEITOSA, K. K. A.; VALE JÚNIOR, J. F.; SCHAEFER, E. G. R.; SOUSA, M. I. L. NASCIMENTO, P. P. R. R. Relações solo-vegetação em "ilhas" florestais e savanas adjacentes, no nordeste de Roraima. Ciências Florestal, v. 26, n. 1, p. 135-146, 2016. http://dx.doi.org/10.5902/1980509821098

FERREIRA, D. F. SISVAR: um programa para análises e ensino de estatística. Revista Symposium, v. 6, p. 36-41, 2008.

FOSTER, G. R.; MCCOOL, D. K.; RENARD, K. G.; MOLDEBHAUER, W. C. Conversion of the universal soil loss equation to SI units. Journal of Soil and Water Conservation, v. 36, n. 6, p. 355-359, 1981.

GUADAGNIN, J. C.; BERTOL, I.; CASSOL, P. C.; AMARAL, A. J. Perdas de solo, água e nitrogênio por erosão hídrica em diferentes sistemas de manejo. Revista Brasileira de Ciência do Solo, v. 29, n. 2, p. 277-286, 2005. http://dx.doi.org/10.1590/S010006832005000200013

GUTH, P. L. Perdas de solo e água por erosão hídrica em sistemas de culturas oleaginosas. 2010. 85p. Dissertação (Mestrado) - Universidade Federal de Santa Maria, Santa Maria, 2010.

LEITE, M. H. S.; COUTO, E. G.; AMORIM, S. S. A.; COSTA, E. L.; MARASCHIN, L. Perdas de solo e nutrientes num Latossolo Vermelho-Amarelo Ácrico Típico, com diferentes sistemas de preparo e sob chuva natural. Revista Brasileira de Ciência do Solo, v. 33, n. 3, p. 689-699, 2009. http://dx.doi.org/10.1590/S0100-06832009000300021

LIMA, G. C.; SILVA, M. L. N.; CURI, N.; SILVA, M. A.; OLIVEIRA, A. H.; AVANZI, J. C.; UMMUS, M. E. Avaliação da cobertura vegetal pelo índice de vegetação por diferença normalizada (IVDN). Revista Ambiente \& Água, v. 8, n. 2, p. 204-214, 2013. http://dx.doi.org/10.4136/ambi-agua.959

MARIOTI, J.; BERTOL, I.; RAMOS, J. C.; WERNER, R. S.; PADILHA, J.; BANDEIRA, D. H. Erosão hídrica em semeadura direta de milho e soja nas direções da pendente e em contorno ao declive, comparada ao solo sem cultivo e descoberto. Revista Brasileira de Ciência do Solo, v. 37, n. 5, p. 1361-1371, 2013. http://dx.doi.org/10.1590/S010006832013000500025

MELO, V. F.; SCHAEFER, C. E. G. R.; VALE JÚNIOR, J. F.; UCHÔA, S. C. P. Aspectos pedológicos e de manejo dos solos de Roraima. In: MELO, V. F.; BARBOSA, R. I, Roraima: homem, ambiente e ecologia. Boa vista: Femact, 2010, p. 391-408.

OLIVEIRA, A. H.; SILVA, M. L. N.; CURI, N.; AVANZI, J. C.; NETO, G. K.; ARAÚJO, E. F. Water erosion in soils under eucalyptus forest as affected by development stages and management systems. Ciência e Agrotecnologia, v. 37, n. 1, p. 159-169, 2013. http://dx.doi.org/10.1590/S1413-70542013000200007

OLIVEIRA, L. C.; BERTOL, I.; BARBOSA, F. T.; CAMPOS, M. L.; MECABÔ JUNIOR, J. Perdas de solo, água e nutrientes por erosão hídrica em uma estrada florestal na serra Catarinense. Ciência Florestal, v. 25, n. 3, p. 655-665, 2015. http://dx.doi.org/10.5902/1980509819616

PANACHUKI, E.; BERTOL, I.; SOBRINHO, T. A.; OLIVEIRA, P. T. S.; RODRIGUES, D. B. B. Perdas de solo e de água e infiltração de água em latossolo vermelho sob sistemas de manejo. Revista Brasileira de Ciência do Solo, v. 35, n. 5, p. 1777-1785, 2011. http://dx.doi.org/10.1590/S0100-06832011000500032 
PANAGOS, P.; BORRELli, P.; MEUSBURGER, K.; ALEWELL, C.; LUGATO, E.; MONTANARELLA, L. Estimating the soil erosion cover-management factor at the European scale. Land Use Policy, v. 48, p. 38-50, 2015. http://dx.doi.org/10.1016/j.landusepol.2015.05.021

PIRES, L. S.; SILVA, M. L. N.; CURI, N.; LEITE, F. P.; BRITO, L. F. Erosão hídrica pósplantio em florestas de eucalipto na região centro-leste de Minas Gerais. Pesquisa Agropecuária Brasileira, v. 41, n. 4, p. 678-695, 2006. http://dx.doi.org/10.1590/S0100204X2006000400021

PUGLIESI, A. C. V.; MARINHO, M. A.; MARQUES, J. F.; LUCARELLI, J. R. F. Valoração econômica do efeito da erosão em sistemas de manejo do solo empregando o método custo de reposição. Bragantia, v. 70, n. 1, p. 113-121, p. 2011. http://dx.doi.org/10.1590/S000687052011000100017

RABELO, M. W. O.; GRIEBELER, N. P. Determinação de incremento de altura de camalhão na integração terraço-estrada. Pesquisa Agropecuária Tropical, v. 42, n. 1, p. 49-55, 2012. http://dx.doi.org/10.1590/S1983-40632012000100007

SANTOS, G. G.; GRIEBELER, N. P.; OLIVEIRA, L. F. C. Chuvas intensas relacionadas à erosão hídrica. Revista Brasileira de Engenharia Agrícola e Ambiental, v. 14, n. 2, p. 115-123, 2010. http://dx.doi.org/10.1590/S1415-43662010000200001

SCHICK, J.; BERTOL, I.; BALBINOT JÚNIOR, A. A.; BATISTELA, O. Erosão hídrica em

Cambissolo Húmico Alumínico submetido a diferentes sistemas de preparo e cultivo do solo: II. perdas de nutrientes e carbono orgânico. Revista Brasileira de Ciência do Solo, v. 24, n. 2, 575 p. 437-447, 2000. http://dx.doi.org/10.1590/S0100-06832000000200019

SHAMSHAD, A.; AZHARI, M. N.; ISA, M. H.; WAN HUSSIN, W. M. A.; PARIDA, B. P. Development of an appropriate procedure for estimation of RUSLE EI30 index and preparation of erosivity maps for Pulau Penang in Peninsular Malaysia. Catena, v. 72, n. 3, p.423-432, 2008.

SILVA, A. M.; SILVA, M. L. N; CURI, N.; LIMA, J. M.; AVANZI, J. C.; FERREIRA, M. M. Perdas de solo, água, nutrientes e carbono orgânico em Cambissolo e Latossolo sob chuva natural. Pesquisa Agropecuária Brasileira, v. 40, n. 12, p. 1223-1230, 2005 b. http://dx.doi.org/10.1590/S0100-204X2005001200010

SILVA, D. D.; PRUSKI, F. F.; SCHAEFER, C. E. G. R. Efeito da cobertura nas perdas de solo em um Argissolo Vermelho-Amarelo utilizando simulador de chuva. Engenharia Agrícola, v. 25, n. 2, p. 409-419. 2005a.

SOANE, B. D.; BALL, B. C.; ARVIDSSON, J.; BASCH, G.; MORENO, F.; ROGERESTRADE, J. No-till in northern, western and south-western Europe: a review of problems and opportunities for crop production and the environment. Soil \& Tillage Research, v. 118, p. 66-87, 2012. http://dx.doi.org/10.1016/j.still.2011.10.015

SOUSA, G. B.; MARTINS FILHO, M. V.; MATIAS, S. S. R. Perdas de solo, matéria orgânica e nutrientes por erosão hídrica em uma vertente coberta com diferentes quantidades de palha de cana-de-açúcar em Guariba - SP. Engenharia Agrícola, v. 32, n. 3, p. 490-500, 2012. http://dx.doi.org/10.1590/S0100-69162012000300008 
SPOHR, R. B.; CARLESSO, R.; GALLÁRRETA, C. G.; PRÉCHAC, F. G.; PETILLO, M. G. Modelagem do escoamento superficial a partir das características físicas de alguns solos do Uruguai. Revista Ciência Rural, v. 39, n. 1, p. 74-81, 2009. http://dx.doi.org/10.1590/S0103-84782009000100012

TELLES, T. S.; DECHEN, S. C. F.; SOUZA, L. G. A.; GUIMARAES, M. F. Valuation and assessment of soil erosion costs. Scientia Agricola, v. 70, n. 3, p. 209-216, 2013. http://dx.doi.org/10.1590/S0103-90162013000300010

VOLK, L. B. S.; COGO N. P. Erosão hídrica, em três momentos da cultura do milho, influenciada por métodos de preparo do solo e semeadura. Revista Brasileira de Ciência do Solo, v. 38, p. 565-574, 2014. http://dx.doi.org/10.1590/S0100-06832014000200021

WISCHMEIER, W. H.; SMITH, D. D. Rainfall energy and its relationship to soil loss. Transaction American Geophysical Union, v. 39, p. 285-291, 1958. http://dx.doi.org/10.1029/TR039i002p00285

WISCHMEIER, W. H.; SMITH, D. D. Predicting rainfall erosion losses. A guide to conservation planning. Washington: USDA Agriculture, 1978. (Handbook, 537).

YEOMANS, J. C.; BREMNER, J. M. A rapid and precise method for routine determination of organic carbon in soil. Communication in Soil Science and Plant Analysis, v. 19, p.1467-1476, 1988.

ZHOU, G. Y.; MORRIS, J. D.; YAN, J. H.; YU, Z. Y.; PENG, S. L. Hydrological impacts of reforestation with eucalypts and indigenous species: a case study in Southern China. Forest Ecology and Management, v. 167, n. 1, p. 209-222, 2002. http://dx.doi.org/10.1016/S0378-1127(01)006946 